University of Michigan Law School

University of Michigan Law School Scholarship Repository

Articles

Faculty Scholarship

2007

\title{
The Meaning of 'Necessary' in GATT Article XX and GATS Article XIV: The Myth of Cost-Benefit Balancing
}

Donald H. Regan

University of Michigan Law School, donregan@umich.edu

Available at: https://repository.law.umich.edu/articles/568

Follow this and additional works at: https://repository.law.umich.edu/articles

Part of the International Trade Law Commons, Organizations Law Commons, and the Transnational Law Commons

\section{Recommended Citation}

Regan, Donald H. "The Meaning of 'Necessary' in GATT Article XX and GATS Article XIV: The Myth of Cost-Benefit Balancing." World Trade Review 6, no. 3 (2007): 347-69.

This Article is brought to you for free and open access by the Faculty Scholarship at University of Michigan Law School Scholarship Repository. It has been accepted for inclusion in Articles by an authorized administrator of University of Michigan Law School Scholarship Repository. For more information, please contact mlaw.repository@umich.edu. 


\title{
The meaning of ' necessary' in GATT Article XX and GATS Article XIV: the myth of cost-benefit balancing
}

\author{
DONALD H. REGAN * \\ William W. Bishop, Jr. Collegiate Professor of Law, University of Michigan
}

\begin{abstract}
Conventional wisdom tells us that in Korea-Beef, the Appellate Body interpreted the word 'necessary' in GATT Article XX to require a cost-benefit balancing test. The Appellate Body is supposed to have applied this test also in EC-Asbestos, US-Gambling (involving GATS Article XIV), and Dominican Republic-Cigarettes. In this article I demonstrate, by detailed analysis of the opinions, that the Appellate Body has never engaged in such balancing. They have stated the balancing test, but in every case they have also stated the principle that Members get to choose their own level of protection, which is logically inconsistent with judicial review by cost-benefit balancing. And they have decided every case by reference to the 'own level of protection' principle. The Appellate Body is right not to balance. Balancing is not authorized by the treaty texts, and it is not needed to prevent inefficient harm to foreign interests.
\end{abstract}

\section{The argument in a nutshell}

In Korea-Beef the Appellate Body interpreted for the first time the word 'necessary' in GATT Article XX, specifically in paragraph XX $(\mathrm{d}) .{ }^{1}$ It is generally believed that the Appellate Body established a cost-benefit balancing test: in order to decide whether a measure is necessary to achieve some specified goal, we 'weigh and balance' the benefits from the measure in the achievement of that goal against the cost of the measure in reduced trade. ${ }^{2}$ I think this is a misunderstanding. The

\footnotetext{
*Email: donregan@umich.edu.

Thanks to Rob Howse, Steve Charnovitz, Federico Ortino, Lorand Bartels, and an anonymous reviewer for comments on previous drafts.

1 Korea-Measures Affecting Imports of Fresh, Chilled and Frozen Beef, WT/DS161 and 169/AB/R (adopted 10 January 2001).

2 E.g., Marceau and Trachtman, 'The Technical Barriers to Trade Agreement, the Sanitary and Phytosanitary Measures Agreement, and the General Agreement on Tariffs and Trade: A Map of the World Trade Organization Law of Domestic Regulation of Goods', 36 Journal of World Trade $(5,2002)$ 811, at 826-828, 851-853; WTO, World Trade Report 2005: Exploring the Links between Trade, Standards and the WTO, at 135, 137-139.
} 
Appellate Body did not establish such a test. But I acknowledge that they made it easy for people to think they did. ${ }^{3}$

The source of the confusion is a logical contradiction at the heart of the Korea-Beef opinion. The Appellate Body does state the balancing test as I just described it. ${ }^{4}$ But elsewhere in the opinion, the Appellate Body also states the principle that a Member pursuing some legitimate domestic goal is entitled to choose for itself the level of achievement of that goal. That is, a Member gets to choose its 'own level of protection'. ${ }^{5}$ Unfortunately, these two pronouncements of the Appellate Body - that measures must be subjected to a balancing test and that Members get to choose their own level of protection - are logically contradictory. A court that is actually applying the balancing test described above must stand ready to say of some measure that: (a) it achieves a legitimate local goal, and (b) there is no other less trade-restrictive way to achieve the same level of that goal, but (c) the measure is nonetheless illegal because the local benefits do not justify the trade costs. But if the Appellate Body actually says that about some measure, then the Member will be prevented from having the level of protection it has chosen in adopting that measure. In case this is not obvious: any alternative measure that achieves the same level of protection will involve equal or greater trade cost, by (b); and any measure that achieves that level of protection at equal or greater cost will fail the balancing test, by (c). So, applying a standard cost-benefit balancing test is inconsistent with allowing the Member to choose its own level of protection.

In the Korea-Beef opinion as a whole, the 'own level of protection' idea gets considerably more play than the balancing approach (even though the 'balancing' passages have got much more attention from commentators). And if we look specifically at the part of the opinion where the case is actually being decided, we see that the Appellate Body relies on the principle that a Member gets to choose its own level of protection. ${ }^{6}$ So the Appellate Body cannot actually be committed to the cost-benefit balancing test described above, whatever they say.

There is a further source of confusion. The concrete test the Appellate Body applies to implement the principle that Members get to choose their own level of protection is a 'less-restrictive alternative test', which is just what is suggested most naturally by the word 'necessary'. But their sophisticated version of the lessrestrictive alternative test itself involves a limited sort of balancing. For a start, the Appellate Body considers as eligible alternatives to the actual measure only other

3 Among those who were not deceived are Howse and Tuerk, 'The WTO Impact on Internal Regulations - A Case Study of the Canada-EC Asbestos Dispute', in G. de Búrca and J. Scott (eds.), The EU and the WTO: Legal and Constitutional Issues (2001), 283, at 324-325; F. Ortino, 'From NonDiscrimination to Reasonableness: A Paradigm Shift in International Economic Law?', Jean Monnet Working Papers 01/2005.

4 162-164, discussed in detail in Section 3.

59176,178 , discussed in detail in Section 3.

$6 \uparrow 180$, discussed in detail in Section 3. 
possible measures that would secure the same level of protection. (This guarantees the Member's right to choose its own level.) But within this class of alternatives, the Appellate Body holds that a Member may have to adopt some alternative measure that is less trade-restrictive than the actual measure, even though the alternative measure involves higher administrative or enforcement costs. To decide whether the Member must adopt the less trade-restrictive measure, the Appellate Body balances the savings in trade cost achieved by the alternative measure against the higher administrative/enforcement cost it entails. If the alternative measure achieves the same level of the ultimate goal at lesser trade cost and without unreasonable additional administrative/enforcement cost, the alternative must be preferred, and the actual measure is not 'necessary'. Conversely, the actual measure is 'necessary' if every alternative measure that achieves the same level of the ultimate goal at lesser trade cost entails unreasonable administrative/ enforcement cost. This mode of decision obviously involves balancing of administrative/enforcement costs against trade costs. But it is not the standard cost-benefit analysis the Appellate Body describes in the most famous passages of Korea-Beef, because it does not involve balancing the achievement of the underlying goal of the measure against the trade costs. As noted, the only alternatives that are eligible for consideration are those that achieve the same amount of the underlying goal.

The difference between these two sorts of balancing is enormously important. To my mind, the most objectionable feature of Korea-Beef and the line of cases that follow it is the suggestion that the Appellate Body is entitled to judge the relative importance of various (non-protectionist) goals the Members might have - human health, animal or plant health, preservation of species, avoidance of noise pollution, restriction of luxury consumption, preventing offense to religious sensibilities, whatever. There is no textual warrant for such judgments of importance by the Appellate Body, and it is a serious intrusion on the Members' regulatory autonomy. ${ }^{7}$ Of course, judging the importance of the local goal in this way is unavoidable if the Appellate Body is actually going to engage in standard cost-benefit balancing. But if the only balancing they engage in does not involve balancing trade costs against the achievement of the underlying goal, but only against administrative/enforcement costs, then there is never any need for the

\footnotetext{
7 The reader might object that Article XX itself implicitly ranks possible goals, by mentioning some and not others. There is some truth in this, although the significance of the positive list in Article XX is less than many people think, if we interpret Article III correctly - that is, as violated only by origin-specific regulations and by origin-neutral regulations with a protectionist purpose - see Regan, 'Regulatory Purpose and "Like Products”'in Article III:4 of the GATT (With Additional Remarks on Article III:2)', 36 Journal of World Trade (3, 2002) 443, and 'Further Thoughts on the Role of Regulatory Purpose Under Article III of the General Agreement on Tariffs and Trade - A Tribute to Bob Hudec', 37 Journal of World Trade (4, 2003) 737. But even if Article XX does imply some ranking, it still does not authorize the Appellate Body to do further ranking on its own, which is what the Appellate Body here proposes to do.
} 
Appellate Body to judge the importance of the underlying goal. This is a great advantage of the less-restrictive alternative approach.

There are three later cases in which the Appellate Body has interpreted the word 'necessary' in GATT Article XX or GATS Article XIV: EC-Asbestos ${ }^{8}$ (involving GATT XX(b)), US-Gambling ${ }^{9}$ (involving GATS XIV(a), which corresponds to GATT XX(a)), and Dominican Republic-Cigarettes ${ }^{\mathbf{1 0}}$ (involving GATT XX(d) again, as in Korea-Beef ). ${ }^{11}$ Unfortunately, the opinions in these later cases merely reproduce the confusion and contradiction of Korea-Beef. All three opinions quote faithfully from Korea-Beef both the statement of a standard cost-benefit balancing test and the statement that each Member gets to choose its own level of protection, with no recognition of the inconsistency. Furthermore, all three opinions do so in such a way as to give prominence to the standard cost-benefit balancing test, reinforcing the general perception that that is 'the test'. Finally, all three follow the lead of Korea-Beef and decide the actual case before them by a 'less-restrictive alternative' test that respects the principle that Members get to choose their own level of protection. Hence none of the later opinions actually involves standard cost-benefit balancing, and none depends on a weighing of the underlying benefit.

There is more to praise in these four opinions (Beef, Asbestos, Gambling, and Cigarettes) than to criticize. I think the Appellate Body is right not to engage in cost-benefit balancing, and the specific results are all defensible, even though I might not have reached the same result as the Appellate Body in DR-Cigarettes. But the doctrinal state of affairs - involving repeated statements of contradictory tests side-by-side - is unfortunate and dangerous. It is unfortunate because we ought to expect logical consistency from the Appellate Body. It is dangerous because as long as the Appellate Body continues to state a standard cost-benefit balancing test in part of each opinion on 'necessity', and as long as trade lawyers continue to believe that such balancing is the applicable test, there is always the possibility that the Appellate Body will be taken in by its own misdescription of what it has been doing and will start actually trying to balance the domestic benefits of a measure against the cost in reduced trade. That would be at odds with the whole spirit of the WTO agreements, which leave the evaluation of domestic benefits to domestic regulators. ${ }^{12}$

8 European Communities - Measures Affecting Asbestos and Asbestos-Containing Products, WT/ DS135/AB/R (adopted 5 April 2001).

9 United States-Measures Affecting the Cross-Border Supply of Gambling and Betting Services, WT/DS285/AB/R (adopted 20 April 2005).

10 Dominican Republic-Measures Affecting the Importation and Internal Sale of Cigarettes, WT/ DS302/AB/R (adopted 19 May 2005).

11 There is passing mention of the 'necessity' issue under Article XX, with a cite to Korea-Beef and a mention of balancing, in Mexico - Tax Measures on Soft Drinks and Other Beverages, WT/DS308/AB/R (adopted 24 March 2006), 974 . But there is no discussion of this issue, and it is perfectly clear that the action in Mexico - Soft Drinks is elsewhere, so I shall ignore this case.

12 See Section 5. 


\section{Logical preliminaries}

\section{Can the less-restrictive alternative test and cost-benefit balancing really be inconsistent?}

I have suggested that in Korea-Beef and its progeny, the principle that Members get to choose their own level of protection is embodied in a sophisticated version of the less-restrictive alternative test. And I have explained why this is inconsistent with standard cost-benefit balancing. But the reader may still wonder how there can be any logical inconsistency. In other contexts we think of the three versions or stages of 'proportionality' analysis - the mere rationality test, the less-restrictive alternative test, and cost-benefit balancing (sometimes known as 'strict proportionality') - as forming a nested sequence of successively more stringent tests. But if the less-restrictive alternative test and cost-benefit balancing are elements in such a nested sequence, it must be possible to apply them both. Applying the lessrestrictive alternative test cannot exclude the possibility of cost-benefit balancing.

The seeming paradox goes away if we are careful to distinguish between positing a test as a necessary condition for the legality of a measure and positing the same test as a necessary-and-sufficient condition for legality. When we think of the rationality test, the less-restrictive alternative test, and cost-benefit balancing as forming a nested sequence, we are implicitly thinking of the first two tests as stating merely necessary conditions for the legality of a measure. In order to be legal, a measure must pass the minimum rationality test; assuming it passes that, then in order to be legal it must also pass the less-restrictive alternative test; and assuming it passes that, then in order to be legal it must also pass the cost-benefit balancing test. Passing the balancing test is necessary-and-sufficient for legality (unless there is some other unrelated test we have not mentioned), but the first two tests are merely necessary conditions. ${ }^{13}$

In contrast, if we think of each of the tests as stating a candidate necessaryand-sufficient condition for legality, then they do not form a nested sequence. They are incompatible. In particular, if the less-restrictive alternative test states not only a necessary condition for legality but also a sufficient condition, then the cost-benefit balancing test cannot state a necessary condition, since it is easy to imagine that some measure passes the less-restrictive alternative test but fails the cost-benefit balancing test as the relevant tribunal would apply it.

But now the crucial point: By relying on the idea that Members get to choose their own level of protection, the Appellate Body in Korea-Beef makes its version of the less-restrictive alternative test necessary-and-sufficient for legality. If there is

13 The claim in the text that passing the balancing test is itself sufficient for legality presupposes that the balancing test is applicable not only to the overall benefits and costs of the measure as compared to inaction, but also to the (marginal) benefits and costs of the measure as compared to any alternative. For a fuller treatment of the logic of this family of tests, see Appendix 2 to Regan, 'Judicial Review of MemberState Regulation of Trade Within a Federal or Quasi-Federal System: Protectionism and Balancing, Da Capo', 99 Michigan Law Review (8, 2001) 1853, at 1899-1902. 
no less trade-restrictive way to achieve the chosen level of protection without unreasonable administrative/enforcement cost, the actual measure is legal, period. There is no logical space left for cost-benefit balancing with the underlying goal. So, it is not just the general statement of a less-restrictive alternative test that is important in Korea-Beef; it is the association of that test with the principle that Members get to choose their own level of protection.

\section{Does granting a margin of appreciation entail cost-benefit balancing?}

I have said it is a great advantage of the less-restrictive alternative approach that it does not require the dispute settlement system to evaluate the importance of the regulator's (non-protectionist) purpose. But we should consider a possible defense of the Appellate Body's claim to engage in such evaluation of purposes. Judgments about whether some proposed 'less-restrictive alternative' actually achieves the Member's chosen level of protection can be controversial. So we are faced with the question of what is the appropriate 'margin of appreciation' that the regulator should be allowed. It might be suggested that the appropriate margin of appreciation varies with the importance of the regulatory goal. For example, we might say the Appellate Body should be more deferential to the national regulator's finding that some alternative is inadequate when the regulation aims at an important goal, so that the cost of mistakenly imposing an alternative that did not achieve the chosen level of protection would be especially high. If this is right, the Appellate Body obviously has to decide how important the regulatory goal is. Furthermore, if this argument is accepted, it may seem to blur the distinction between the lessrestrictive alternative test and cost-benefit balancing, since the more important the goal, the more likely it is that the regulation will prevail.

There are two principal points to make in response. First, even if the Appellate Body behaves as suggested, that does not convert the less-restrictive alternative test into cost-benefit balancing. Sometimes it is tolerably clear, without any attention to the importance of the goal or the margin of appreciation, that there is no lessrestrictive alternative that achieves the chosen level of protection. In that case, under a less-restrictive alternative test, the regulation is upheld; under cost-benefit balancing, it still faces another hurdle. Second, to the extent the Appellate Body considers the importance of the purpose, the real question should not be about the importance of the purpose in the abstract, or by the Appellate Body's standards; it should be about the importance of the purpose to the Member whose regulation is in question. The proper measure of the harm done by an improper invalidation is the damage to the Member's purposes as it values them. Of course, in assessing the importance of the purpose to the Member, the tribunal cannot help but be influenced by views that are widely shared by other Members, or that are endorsed by major multilateral treaties, or even by the tribunal's own substantive views. But the tribunal should do its best to remember that those are all merely heuristics. The real question is about the importance of the purpose to the Member, and if it is clear that the Member has an eccentric view, that view 
should nonetheless be respected. The WTO imposes no general ranking of (nonprotectionist) goals. ${ }^{14}$

There is another way in which granting an extra margin of appreciation when the regulatory purpose is important is not like traditional cost-benefit balancing. Granting an extra margin of appreciation is a regulator-friendly move. Of course, giving a greater margin of appreciation when the purpose is important logically entails giving a relatively lesser margin of appreciation when the purpose is less important; but I have just pointed out that, even without any margin of appreciation at all, if it is clear there is no less-restrictive alternative, the respondent Member wins. So the margin of appreciation works in principle to the regulator's advantage. In contrast, traditional cost-benefit balancing, applied as a third-stage test after the minimum rationality test and the less-restrictive alternative test, is definitely not to the regulator's advantage; it is an additional hurdle. So the thrust of the expanded margin of appreciation for 'important' purposes is entirely opposite to the thrust of cost-benefit balancing. Incidentally, when we discuss the Korea-Beef opinion in detail, we shall see that at crucial points, balancing is cast in the role of a help to the regulator, not a hurdle. In context, there is another explanation of that beside the present point about the margin of appreciation; but, in any event, this slant on the role of balancing supports my claim that the Appellate Body is not imposing a standard cost-benefit balancing test.

\section{The Korea-Beef opinion}

I have argued that the Appellate Body in Korea-Beef posits, and claims to apply, two contradictory tests. How did the Appellate Body get itself into such a mess? I do not have a complete answer, but we can at least watch it happen if we go through the relevant portion of the Korea-Beef opinion step by step. We begin with the famous $\$ 160$, in which the Appellate Body observes that although 'the word "necessary" normally denotes something "that cannot be dispensed with or done without, requisite, essential, needful ", , a 'standard law dictionary' says that in different contexts 'necessary' may mean anything from 'indispensable' to merely 'convenient'.

The Appellate Body then continues in $\$ 161$ :

We believe that, as used in the context of Article XX(d), the reach of the word 'necessary' is not limited to that which is 'indispensable' or 'of absolute necessity' or 'inevitable'. Measures which are indispensable or of absolute necessity or inevitable to secure compliance certainly fulfill the requirements of

14 With regard to whether Article XX itself imposes some ranking, see n. 7 above. Incidentally, there is a threshold question, which arises before we even get to the 'margin of appreciation' issue, whether the claimed purpose of a measure is the Member's true purpose. General views about the value of various purposes, and thus the likelihood of Members' pursuing them, are relevant here too, but with the same caveat that they are relevant only as heuristics. 
Article $\mathrm{XX}(\mathrm{d})$. But other measures, too, may fall within the ambit of this exception.

In the last two sentences just quoted, the Appellate Body says (a) that a measure which is indispensable is ('certainly') 'necessary', and (b) that a measure may be 'necessary' without being indispensable. I will come back to (b) in a moment. But notice first that by asserting (a) the Appellate Body, before it even mentions balancing, has already excluded the possibility of a generally applicable cost-benefit balancing test. There is no guarantee that a measure which is indispensable to secure the regulator's goal could not still fail a balancing test. But the Appellate Body says that a measure which is indispensable ipso facto fulfills the requirements of Article $\mathrm{XX}(\mathrm{d})$. So, there is no room for a balancing test when the measure is indispensable.

In fact, asserting (a) does even more. In addition to logically excluding balancing in some cases, it makes it implausible that we should ever want to engage in standard cost-benefit balancing in any case at all, because the cases it excludes are the only ones where such balancing could make any sense from a logical point of view. Consider. We know that if the measure is indispensable, it is legal, period. That leaves cases where the measure is not indispensable, that is, where there is some alternative way to achieve the domestic goal to the same extent. Now there are two subcases. One possibility is that the alternative measure that achieves the same domestic benefit has the same or higher trade cost. Obviously we are not going to require the Member to switch to the alternative measure in such a case, and it does not require any balancing to tell us so. The other possibility is that the alternative measure that achieves the same domestic benefit has a lower trade cost. Now it is clear that we $d o$ want to require the use of the alternative measure, since it secures the same benefit at lesser cost, and once again we do not need balancing to tell us so. So there is no case in which we need to balance.

Actually, when I say it is clear we do want to require use of an alternative measure that achieves the same benefit at lesser trade cost, I am ignoring administrative and enforcement costs, as we frequently do in abstract discussions. The Appellate Body rightly recognizes later in its opinion that we cannot completely ignore administrative and enforcement costs. It implies that we should not require the use of the alternative measure, even though it achieves the same domestic benefit at lesser trade cost, if the administrative and enforcement costs of the alternative are excessive $\$ 173,179$, relying on findings of the Panel that the costs would not be excessive in this case). In fact, the Appellate Body has already anticipated this point in (b) above; this is why a measure may be 'necessary' even though it is not indispensable. At this point the comparison that is called for between the actual measure and the alternative measure requires us to balance the extra administrative/enforcement cost of the alternative measure against the saving in trade cost from the alternative measure, but this is still not standard cost-benefit balancing. Specifically, it does not require any weighing of the domestic benefit 
that is the underlying goal of the measure (consumer protection, health, or whatever). By hypothesis the two measures being compared achieve the same level of that benefit, so we can ignore it in comparing the two. In sum, there is no case in which we actually need to engage in the sort of balancing that involves weighing the underlying domestic benefit of the measure.

As the preceding paragraphs indicate, both (a) and (b) are distinctly regulatorfriendly moves. The assertion of (a) excludes cost-benefit balancing when the actual measure is the least trade-restrictive way to achieve the desired level of protection; this is a regulator-friendly move because balancing is a more stringent test than a 'less-restrictive alternative' or 'indispensability' test. But as we have seen, (b) weakens the test still further, by saying that some measures may count as 'necessary' even though they are not the least trade-restrictive way to achieve the desired level of protection, if the administrative/enforcement costs of any less trade-restrictive alternative are too great. It is a pity that the Appellate Body does not pause at this point to explain (as I just have) why some measure might count as 'necessary' even without being indispensable. They do explain this later on, but if they had done it here the whole opinion might have played out differently. However, instead of developing the logic of the two sentences we have so far focused on, they turn (still in 9161 ) to the realm of metaphor. They opine that the term 'necessary' in Article XX(d) refers to 'a range of degrees of necessity' constituting a 'continuum' with the meaning 'indispensable' at one end and the meaning 'making a contribution to' at the other. They then say that a 'necessary' measure is "located significantly closer to the pole of "indispensable" than to the opposite pole of simply "making a contribution to",

The Appellate Body now begins $\$ 162$ by reminding us of the special features of Article $\mathrm{XX}(\mathrm{d})$. Article $\mathrm{XX}(\mathrm{d})$ is about measures designed to ensure compliance with other laws and regulations, and the Appellate Body points out that ' $\mathrm{XX}(\mathrm{d})$ is susceptible of application in respect of a wide variety of "laws and regulations", The Appellate Body famously continues:

It seems to us that a treaty interpreter assessing a measure claimed to be necessary to secure compliance of [sic] a WTO-consistent law or regulation may, in appropriate cases, take into account the relative importance of the common interests or values that the law or regulation to be enforced is intended to protect. The more vital or important those common interests or values are, the easier it would be to accept as 'necessary' a measure designed as an enforcement instrument.

This is a surprising suggestion in a number of respects. First, it seems to constitute a break in the line of reasoning. At the end of 161 , the Appellate Body deployed the metaphor of a 'continuum' of 'degrees of necessity' of a regulatory measure to the achievement of a specified purpose. The problem was to locate 'necessary' on that continuum. There is nothing in this metaphor that suggests an inquiry into the value of the purpose itself, since the purpose is the same all along the continuum. Furthermore, there is nothing in the text of Article $\mathrm{XX}(\mathrm{d})$ to suggest that different 
regulatory purposes are accorded different values by Article XX(d). A fortiori, there is nothing to suggest that it is appropriate for the Appellate Body to rank Members' regulatory purposes according to the Appellate Body's intuitions about their value.

Why does the Appellate Body, which has so often paraded its concern for the text, make such a move? I do not claim to know, but one might speculate that the Appellate Body members, knowing they were going to emphasize each Member's right to choose its own level of protection later in the opinion, were worried that if Members could choose their own level of protection with regard to just any purpose at all, there would simply be too much regulatory freedom, too much interference with trade (or from another perspective, too little Appellate Body control). Leaving aside the question whether the Appellate Body should decide for itself, independently of the text, how much regulatory freedom (or how much Appellate Body control) there should be, this is surprising in a new way. As I have explained, 161 of the opinion is notably regulator-friendly. But $\uparrow 162$, on this understanding, is notably regulator-unfriendly. Regulators are now not to be trusted with the freedom they were conceded earlier. It is this ambivalence of the Appellate Body about how much freedom regulators should have that generates the contradiction I pointed out in the Introduction between the balancing test, first intimated here in 162 , and the idea that Members get to choose their own level of protection, which was just stated, although not in those terms, in $\$ 161$ and which will be stated again in precisely those terms later in the opinion.

So, 162 seems, surprisingly, to introduce a standard cost-benefit balancing test. If $\uparrow 162$ stood alone, it might be taken to suggest merely that there should be a greater margin of appreciation for regulations pursuing important purposes, as we suggested in Section 2. This would be the charitable interpretation, since it avoids introducing any logical inconsistency into the opinion. But the next two paragraphs of the report make this 'non-balancing' reading much less plausible:

163. There are other aspects of the enforcement measure to be considered in evaluating the measure as 'necessary'. One is the extent to which the measure contributes to the realization of the end pursued, the securing of compliance with the law or regulation at issue. The greater the contribution, the more easily a measure might be considered to be 'necessary'. Another aspect is the extent to which the compliance measure produces restrictive effects on international commerce, [footnote omitted] that is, in respect of a measure inconsistent with Article III.4, restrictive effects on imported goods. [Emphasis in original.] A measure with a relatively slight impact upon imported products might more easily be considered as 'necessary' than a measure with intense or broader restrictive effects.

164. In sum, determination of whether a measure, which is not 'indispensable', may nevertheless be 'necessary' within the contemplation of Article $\mathrm{XX}(\mathrm{d})$, involves in every case a process of weighing and balancing a series of factors which 
prominently include the contribution made by the compliance measure to the enforcement of the law or regulation at issue, the importance of the common interests or values protected by that law or regulation, and the accompanying impact of the law or regulation on imports or exports.

By now the Appellate Body seems quite clearly to be stating a cost-benefit balancing test. To be sure we could still take the whole 'weighing and balancing' discussion of $\uparrow 162-164$ as just about the margin of appreciation in applying the less-restrictive alternative test. But that is a strained reading - especially since the Appellate Body never mentions the margin of appreciation - and it is not the way this passage has been commonly understood. As I have explained in Section 2, if this passage is just about the margin of appreciation in applying the less-restrictive alternative test, that is very different from the cost-benefit balancing the passage is usually thought to require.

Putting the margin-of-appreciation interpretation aside, we should note that if the Appellate Body thought a balancing approach was necessary to account for the significance of each of the three factors they name, they were mistaken. Both of the considerations mentioned in $\$ 163$ - the amount of the desired benefit the measure achieves and the trade cost it imposes - are fully relevant to a lessrestrictive alternative test that involves no balancing. In order to know whether a suggested 'alternative' to the actual measure achieves the same level of the benefit, we have to know how much the actual measure achieves. And just as the Appellate Body says in $\uparrow 163$, the more benefit the actual measure achieves, the more likely it will be found 'necessary' (even without doing any cost-benefit balancing), because the less likely it is that there is an alternative measure that is less trade-restrictive and that achieves as much. Similarly, in order to know whether a suggested 'alternative' to the actual measure is less trade-restrictive, we need to know how trade-restrictive the actual measure is. And once again, just as the Appellate Body says in $\uparrow 163$, the less trade-restrictive the actual measure is, the more likely it will be found 'necessary' (even without doing any cost-benefit balancing), because the less likely it is that there is an alternative measure that achieves the same benefit and that restricts less. In fact, the only consideration in the Appellate Body's list that is relevant to a cost-benefit balancing test and not to a less-restrictive alternative test is the value of the regulatory purpose, which as we have already seen is a seriously suspect consideration.

Notice also, before we go on, that the contradiction that infects the opinion as a whole is fully manifested in the famous sentence that constitutes 9164 . I think most people remember that sentence as if it said: 'In sum, determination of whether a measure is "necessary", within the contemplation of Article XX $(\mathrm{d})$, involves in every case a process of weighing and balancing ... [of the factors mentioned in $\uparrow 162,163]$.' But it does not say that. It says, 'In sum, determination of whether a measure, which is not "indispensable", may nevertheless be "necessary" ... [involves balancing]' (emphasis added). Right here at the heart of the supposed balancing test, we are reminded explicitly that the test does not apply 
if the measure is actually indispensable. But as I explained already, this is the only case where traditional cost-benefit balancing could actually make any contribution to the analysis, as a logical matter. And there is a further revealing feature of the syntax. The Appellate Body says, 'In sum, determination of whether a measure, which is not "indispensable", may nevertheless be "necessary" ... [involves balancing]' (emphasis added). The measure that is not indispensable is (by implication) presumptively not necessary, but it may nevertheless turn out to be 'necessary'; it may be rescued, as it were, by a balancing inquiry. We normally think of the balancing test as a hurdle the measure must get over, and that is the right way to think about the standard cost-benefit balancing test, if we apply it. But here balancing is portrayed implicitly as a life-preserver the measure may be able to catch. This makes sense only if the balancing we are now talking about is the sort described earlier as a kind of safety-valve on the less-restrictive alternative test, which allows a measure to be found 'necessary' even though there is a less-trade-restrictive alternative available that achieves the same benefit, if the alternative measure involves enough extra administrative/enforcement costs to outweigh the savings in trade cost. This is the very test stated later in the opinion. And as I have pointed out previously, this test requires no evaluation of the importance of the underlying benefit pursued by the measure.

In $\uparrow 165$ the Appellate Body leaves cost-benefit balancing and goes back to the less-restrictive alternative test, although it is not immediately clear that this is what is happening. The Appellate Body begins by quoting from the GATT Panel report in US - Section $337^{15}$ on the meaning of 'necessary' in Article $\mathrm{XX}(\mathrm{d})$ :

[A] contracting party cannot justify a measure inconsistent with another GATT provision as 'necessary' in terms of Article $\mathrm{XX}(\mathrm{d})$ if an alternative measure which it could reasonably be expected to employ and which is not inconsistent with other GATT provisions is available to it. By the same token, in cases where a measure consistent with other GATT provisions is not reasonably available, a contracting party is bound to use, among the measures reasonably available to it, that which entails the least degree of inconsistency with other GATT provisions.

This sounds like a less-restrictive alternative test, not cost-benefit balancing, except that the Appellate Body immediately says in $\$ 166$ that this Section 337 standard

encapsulates the general considerations we have adverted to above. In our view the weighing and balancing process we have outlined is comprehended in the determination of whether a WTO-consistent alternative measure which the Member concerned could 'reasonably be expected to employ' is available, or whether a less WTO-inconsistent measure is 'reasonably available'.

15 United States - Section 337 of the Tariff Act of 1930, BISD 36th Supp. 345 (adopted 7 November 1989), - 5.26. 
So what is it, less-restrictive alternative or balancing? There is room for doubt because of an ambiguity in the notion of an 'alternative' measure. If an eligible 'alternative' measure must be one which achieves the same level of the benefit sought by the actual regulation, then we have a less-restrictive alternative test. There is no place for cost-benefit balancing, and there is no need for a ranking of regulatory purposes. Any balancing to determine whether an alternative is 'reasonably available' must be a matter of weighing the reduction in trade cost it achieves (as compared to the actual measure) against any additional administrative/enforcement cost. In contrast, we might just mean by an 'alternative' measure one which achieves 'some considerable amount' of the benefit sought by the actual measure, or one which achieves 'almost as much' of that benefit as the actual measure. And we would then most naturally mean by an alternative that is 'reasonably available', or that the Member 'could reasonably be expected to employ', a measure whose saving in trade cost outweighs (in the opinion of the Appellate Body) the reduction in the achievement of the Member's objective. This is cost-benefit balancing, and this does require the valuing by the Appellate Body of Members' regulatory purposes. So, what kind of balancing we are doing depends on what we mean by an 'alternative'.

The Appellate Body allows this crucial ambiguity to persist for the next few paragraphs, in which it works through the Korea-Beef Panel's treatment of the facts. Happily, we do not need to analyze these paragraphs in detail. At the beginning of $\uparrow 176$ the ambiguity about what counts as an 'alternative' is finally resolved: 'It is not open to doubt that Members of the WTO have the right to determine for themselves the level of enforcement of their WTO-consistent laws and regulations.' This means, obviously, that a measure that does not achieve the same level of protection is not an eligible alternative, whatever its other virtues. And the Appellate Body points out that this was the view of the Section 337 Panel also. They quote that Panel as saying that the obligation to choose a reasonably available alternative measure 'does not mean that a contracting party could be asked to change its substantive patent law or its desired level of enforcement of that law'(emphasis added by the Appellate Body). ${ }^{16}$ In other words, Members get to choose their own level of protection (provided, the Section 337 Panel adds, that they enforce the same level of protection against harm from imported and like domestically produced products).

The next three paragraphs, $\uparrow 177-179$, also do not require detailed analysis. They deal with the issue of what Korea's chosen level of protection actually is, and they can be summed up in the eminently sensible proposition that Korea cannot assert a 'desired level of protection' that is higher than the level achieved by the actual measure and then hold proposed alternatives to the standard Korea asserts as opposed to the standard its actual measure achieves. This is not to deny that Korea may genuinely want a higher level than they are able to achieve. Even so, it

16 Korea-Beef, $\uparrow 176$, quoting US - Section 337, ๆ5.26. 
is obvious that a proposed alternative should not be required to achieve more benefit than the actual measure. ${ }^{17}$

The Appellate Body finally summarizes in $\$ 180$ its rationale for holding against Korea, and it makes clear again that the operative test - the test on which it explicitly relies to justify the result in the case - is the sophisticated less-restrictive alternative test:

We share the Panel's conclusion. We are not persuaded that Korea could not achieve its desired level of enforcement of the Unfair Competition Act with respect to the origin of beef sold by retailers by using conventional WTO-consistent measures, if Korea would devote more resources to its enforcement efforts on the beef sector.

In other words, Korea loses because the Appellate Body is not persuaded that they could not achieve the same benefit at lesser cost to trade, if they just spent somewhat more (but, implicitly, not an unreasonable extra amount in light of the trade cost avoided) on enforcement. This rationale involves no balancing with the fraudprevention benefit because the amount of that benefit achieved does not vary between the measures (actual and alternative) being compared. It follows that this rationale requires no determination by the Appellate Body of the importance of fraud-prevention.

In this connection it is worth mentioning that, although the Appellate Body raises the issue of the importance of the regulatory goal in $\$ 162,164$, it never actually tells us anywhere in the opinion how important it thinks Korea's goal of fraud-prevention is. Many readers probably assume the Appellate Body does tell us about the importance of Korea's purpose implicitly: the Appellate Body says the importance of the Member's purpose matters; Korea loses; so we can infer that Korea's purpose was relatively unimportant. If the opinion as a whole established that the Appellate Body was balancing, this argument would be suggestive (although not conclusive) about how the Appellate Body valued fraud-prevention. But in fact the Appellate Body ultimately states a rationale that does not require evaluation of the Member's purpose. In this context, their failure to follow through on the issue of the importance of the regulatory purpose simply confirms, to my mind, that it is not a significant issue after all. ${ }^{18}$

17 The Appellate Body wrestles unsatisfactorily with a similar sort of question in Australia - Measures Affecting Importation of Salmon, WT/DS18/AB/R (adopted 6 November 1998), part V.D. I am not sure why they do not see what seems clear after the briefest reflection: that when we are applying a lessrestrictive alternative test, the 'level of protection' we should require from proposed alternatives is (a) the level achieved by the actual measure, or (b) the level the Member asserts as its desired level, whichever is lower (that is, whichever is less protective).

18 We shall see below that after deciding four cases on 'necessity', the Appellate Body has yet to say of any legitimate purpose that it is not important; and in US-Gambling they seem to imply that fraudprevention in particular is important. Actually, the Appellate Body does seem to have a somewhat jaundiced view of Korea's purpose in the present case; but the best explanation is not that they see fraudprevention as unimportant. Rather, they suspect that Korea's actual purpose is not origin-neutral fraud-prevention. Remember the observation from the Section 337 Panel that the regulating Member can 
In sum, the Appellate Body does not engage in cost-benefit balancing in Korea-Beef. To be sure, they state a cost-benefit balancing test in three paragraphs of the opinion ( $\uparrow 162-164)$. But we have seen that they also state a different test, which is logically incompatible with cost-benefit balancing, both before those balancing paragraphs (in 161), and again after them (in $\uparrow 176,180$ ), and indeed in the middle of one of them (164). And it is this other test, based on the idea that each Member gets to choose its own level of protection, that they explicitly rely on in 180 when they actually decide the case.

\section{Rehashing Korea-Beef: Asbestos, Gambling, and Cigarettes}

Let us look now at the three Appellate Body reports that have followed Korea-Beef. Happily, we will not need to parse any of them in the same detail as Korea-Beef. The main point, as I said in the Introduction, is that all three reproduce the basic schematism of Korea-Beef. All three restate the Korea-Beef balancing test; all three also state that Members are entitled to choose their own level of protection; none notices that there is a logical contradiction here; and when it comes to actually deciding the case, all three rely on the principle that Members get to choose their own level of protection.

\section{EC-Asbestos}

Consider first Asbestos. The Appellate Body begins by saying in 168 that Members are entitled to choose their own level of protection: '[I]t is undisputed that WTO Members have the right to determine the level of protection of health that they consider appropriate in a given situation.' A few paragraphs later, in -172, the Appellate Body refers to Korea-Beef and its 'weighing and balancing process':

We indicated in Korea-Beef that one aspect of the 'weighing and balancing process ... comprehended in the determination of whether a WTO-consistent alternative measure' is reasonably available is the extent to which the alternative measure 'contributes to the realization of the end pursued'. In addition, we observed, in that case, that ' $[\mathrm{t}]$ he more vital or important [the] common interests or values' pursued, the easier it would be to accept as 'necessary' measures designed to achieve those ends. In this case, the objective pursued by the measure is the preservation of human life and health through the elimination, or reduction, of

choose its own level of protection, but it must seek the same level of protection against harm from foreign products and like domestic products. The Korea-Beef Appellate Body was plainly troubled by the fact that Korea seemed to care less about domestic dairy beef being passed off as Hanwoo beef than about foreign beef being passed off (168). This looks like having a higher level of protection when the harm is from a foreign product. (Related to the idea that Korea seems to want a higher level of protection against harm from foreign beef is the Appellate Body's complaint that the dual retail system puts 'all, or the great bulk' of the costs of fraud-prevention on the foreign beef, as opposed to spreading the costs between domestic and foreign beef ( $\uparrow 181)$.) 
the well-known, and life-threatening, health risks posed by asbestos fibres. The value pursued is both vital and important in the highest degree. The remaining question, then, is whether there is an alternative measure that would achieve the same end and that is less restrictive of trade than a prohibition. [Footnotes omitted.]

In 174 , the Appellate Body tells us that Canada's proposed alternative to France's measure, 'controlled use', would not allow France to achieve 'its chosen level of health protection'. And in $\$ 175$ it tells us that 'for these reasons', France’s measure is 'necessary' under Article $\mathrm{XX}(\mathrm{b})$ because there is no reasonably available alternative to the actual measure.

The one thing the Appellate Body does not do is show any awareness of the logical contradiction between a balancing approach and the idea that France gets to choose its own level of protection. So we should ask whether they have hit on some way to make the contradiction go away. One possibility is that the Appellate Body is saying that a WTO Member gets to choose its own level protection, provided the goal of the measure is 'vital' or 'important'. So long as the goal is of this favored sort, the Appellate Body does not balance, but with less important goals it might. In support of this, it might be noted that whenever the Appellate Body speaks most explicitly in Asbestos of France's (or a Member's) right to choose its own level of protection, it speaks of the right to choose the level of health protection $(\uparrow 168,174)$. On the other hand, they never say explicitly that the right to choose the level of protection is limited to cases involving health or life or other 'important' values. Indeed, their first statement of the principle, in $\$ 168$, although it mentions health, otherwise closely tracks language from Korea-Beef and US - Section 337, in which there is no such qualification. Also, US-Gambling cites Asbestos for this idea without limitation to health. ${ }^{19}$ It seems most natural to suppose that the Asbestos Appellate Body refers to health simply because that is the regulatory goal the case involves, and not because they are trying to sneak in a limitation on the Member's fundamental right to choose its own level of protection sub silentio.

Considering the 'important value' idea in its own right, there is reason to think the Appellate Body does not take it all that seriously. In four cases the Appellate Body has yet to say that any specific regulatory goal is not 'vital' or 'important'. In Asbestos, human life and health are vital and important. That's easy. But in DR-Cigarettes the Appellate Body apparently endorses the Panel's view that collecting tax revenue on cigarettes is vitally important. ${ }^{20}$ As I have already remarked, people may read Korea-Beef as implying that preventing consumer fraud is not within the Appellate Body's charmed circle of preferred purposes, but the report does not actually say any such thing. And in US-Gambling the Appellate Body

19 US-Gambling, 308 n. 379.

20 DR-Cigarettes, $\uparrow 71$. The Panel did suggest that this sort of purpose might be specially important for developing countries, but we can hardly make such a distinction part of the legal test of 'necessity'. 
makes no objection to the Panel's finding that all of the United States' purposes, which include the prevention of consumer fraud, are important. ${ }^{21}$ We might of course say that with four purposes involved in Gambling, the Appellate Body wasn't paying careful attention to each. Or we might say that the consumer fraud in Gambling, which would presumably involve actual loss of money, was worse than the consumer fraud in Korea-Beef, which involved getting perfectly edible foreign beef instead of a preferred luxury domestic version. But the more hairs of this sort the tribunals split, the more suspect the whole process would become. In sum, the Appellate Body has yet to say that any specific legitimate regulatory purpose is less valuable than any other. So far so good.

\section{US-Gambling}

In US-Gambling we see once again all the inconsistent elements of Korea-Beef. First we read in 1305 , 'In Korea-Various Measures on Beef, the Appellate Body stated, in the context of Article XX(d) of the GATT 1994, that whether a measure is "necessary" should be determined through "a process of weighing and balancing a series of factors".' In $\$ 306$, 'The process begins with an assessment of the "relative importance" of the interests or values furthered by the challenged measures.' And so on through the Korea-Beef 'factors'. The first two sentences of T308 remind us that even if a less-restrictive measure is available, the Members may not be required to use it if its administrative/enforcement costs are excessive. Then the last sentence of $\uparrow 308$ : "Moreover, a "reasonably available" alternative measure must be a measure that would preserve for the responding Member its right to achieve its desired level of protection with respect to the objective pursued under paragraph (a) of Article XIV [of GATS]' (emphasis added). By this point, the Appellate Body has transformed the cost-benefit balancing test into its logical contrary - all unaware of the contradiction.

There is no single sentence in the Gambling report that encapsulates the decisive rationale quite as neatly as in Korea-Beef or Asbestos, but the closest thing to such a sentence is in 9317 : "In our view, the Panel's "necessity" analysis was flawed because it did not focus on an alternative measure that was reasonably available to the United States to achieve the stated objectives regarding the protection of public morals or the maintenance of public order' (emphasis added). There are ten more paragraphs in the 'necessity' analysis, devoted to explaining why consultation with Antigua was not, as the Panel thought, a relevant alternative, and why the Appellate Body could then complete the analysis and find for the United States, since no other alternative had even been suggested. These last ten paragraphs talk about 'alternatives' or 'reasonably available alternatives' without explicitly addressing the ambiguity mentioned earlier about whether an 'alternative' must achieve the Member's desired level of protection. But there is no reason to doubt 
that this requirement, stated explicitly in $\uparrow 317$, is continued implicitly throughout the remaining discussion.

There is one interesting wrinkle in the Gambling report's treatment of necessity. Gambling is the only report that wrestles with the question of what counts as a prima facie case of 'necessity'. 'Necessity' is of course part of a defense, so by a standard principle, the burden is on the respondent Member to present at least a prima facie case of 'necessity'. But if 'necessity' depends on the non-existence of a less-restrictive alternative, then a requirement to prove necessity is a requirement to prove a negative, which another standard principle says we should not impose. The Gambling Appellate Body is completely clear that the respondent Member does not have to canvass and show the inadequacy of every imaginable alternative measure $(\uparrow 309,320)$; at some point it is up to the complaining Member to suggest 'reasonably available alternatives' $(\uparrow 320,326)$. But what must the respondent Member do first? Something, surely, if there is to be any initial burden on the respondent Member at all.

The Gambling report can be read as making the interesting suggestion that the Korea-Beef 'balancing' approach constitutes the respondent Member's prima facie case (1323-325). Once the prima facie case is made in this way, then we move on to a less-restrictive alternative analysis that respects the respondent Member's right to choose its own level of protection and that requires the challenging country to suggest alternative measures. Now, this cannot be quite right. If the prima facie case involves full-fledged cost-benefit balancing, we may cut off the Member's right to choose its own level of protection then and there, which by hypothesis we do not mean to do. But there is a way to make some considerable sense of the Appellate Body's discussion here. Remember that two of the three Korea-Beef factors - the degree to which the challenged measure advances the regulatory goal and the degree of trade-restrictiveness - are fully relevant to a lessrestrictive alternative analysis. ${ }^{22}$ And if we ask what might constitute a prima facie case of necessity (which is to say, of the absence of an eligible alternative), without requiring the respondent Member to canvass all possible alternatives, it may be that there is no better way to describe this than to say the Member must show a high enough level of goal-achievement from the measure, and a low enough level of trade-restriction, so that it seems plausible (pending the suggestion of alternative measures by the complaining Member) that there is no alternative measure that can achieve that much of the goal with less trade-restriction and at reasonable administrative/enforcement cost. This might seem like a sort of proto cost-benefit balancing (although it is not the real thing, since the desired level of protection is respected). ${ }^{23}$

22 See Section 3 above.

23 Notice incidentally that the Appellate Body's approach, as I have elaborated it, does not involve shifting the final burden of proof on the 'necessity' exception to the complaining Member. Once the respondent Member has made a prima facie case for the necessity of its measure, as described in the text, it is up to the complaining Member to propose some alternative; but once the complaining Member 


\section{DR-Cigarettes}

Dominican Republic-Cigarettes adds nothing of interest with regard to the necessity defense. Like the other cases, it restates the Korea-Beef balancing test, citing also both Asbestos and Gambling ( $\mid 66,68,69-70)$. It also states the incompatible principle that Members get to choose their own level of protection, quoting from Gambling a sentence we have already noted: 'Moreover, a "reasonably available" alternative measure must be a measure that would preserve for the responding Member its right to achieve its desired level of protection with respect to the objective pursued' (\$70, quoting Gambling 9308). The Appellate Body then explains its ultimate resolution of the case in terms of the latter principle. In 972 the Appellate Body summarizes thus the Panel's reasoning (which it then endorses in 973 ):

[T] he alternative of providing secure tax stamps to foreign exporters, so that those tax stamps could be affixed on cigarette packets in the course of their own production process, prior to importation, would be equivalent to the tax stamp requirement in terms of allowing the Dominican Republic to secure the high level of enforcement it pursues with regard to tax collection and the prevention of cigarette smuggling. [Emphasis added.]

\section{Taking stock}

The lesson of all four cases - Beef, Asbestos, Gambling, and Cigarettes - is that, despite what the Appellate Body says in some parts of these opinions, it is not engaged in cost-benefit balancing. Beef and Cigarettes may seem inconclusive on their own; in both cases the challenged measure fails the less-restrictive alternative test, so we do not know for certain that the Appellate Body would not have gone on to cost-benefit balancing if the measure had passed the less-restrictive alternative test. But in both Asbestos and Gambling, the measure passes the less-restrictive alternative test, and that is the end of the matter. Someone might claim that in Asbestos the Appellate Body does balance, but there is no need to go through the steps explicitly because the result is so obvious. In Gambling too, the hard-core defender of balancing could insist that cost-benefit balancing is going on unconsciously, or sub rosa. But despite the confusion the Appellate Body itself has sown, the full opinions in all four cases strongly suggest that the determinative principle is the principle that Members get to choose their own level of protection, which excludes cost-benefit balancing. The claim that the Appellate Body is 'really' balancing, whatever it says, is the sort of claim it is impossible to disprove. But if we are trying to account for a data set, we should accept the simplest adequate explanation. The simplest adequate explanation for the results in these cases is that the Appellate Body is deciding the cases by a less-restrictive alternative

proposes a minimally plausible alternative measure, the burden is still on the respondent Member to show that the alternative does not achieve the desired level of protection, or is not less trade-restrictive, or involves excessive administrative/enforcement costs. 
test, just as it says it is in the parts of the reports where the results are finally announced and justified.

\section{Why the Appellate Body is right not to balance: treaty text and economic theory}

I have argued that the Appellate Body does not engage in cost-benefit balancing. In this section I shall explain briefly why they are right not to. First, they are right as a matter of interpretation of the WTO texts. If we think about ordinary meaning in context, the word 'necessary' in GATT Article XX and GATS Article XIV suggests a less-restrictive alternative approach much more naturally than it suggests a cost-benefit balancing approach. Furthermore, we have seen that cost-benefit balancing is incompatible with the principle that Members get to choose their own level of protection. The right to set one's own level of protection was recognized under GATT before the WTO came into existence ${ }^{24}$ and the right is mentioned specifically in the SPS and TBT Agreements. ${ }^{25}$ Starting from the other direction, if we consider what sorts of limitations the WTO clearly imposes on Members' regulatory autonomy, they are, roughly speaking: (a) the specific commitments made in Members' schedules under various agreements, (b) provisions in a number of agreements designed to limit non-tariff protectionism (including subsidies), ${ }^{26}$ and (c) a ban on sanitary, phytosanitary, and technical measures that are more trade-restrictive than necessary to achieve the regulating Member's goals. ${ }^{27}$ None of these limitations requires cost-benefit balancing, and there is nothing else in the texts to suggest that the dispute system is authorized to subject measures to cost-benefit balancing. Judicial review by cost-benefit balancing is not in the spirit of the WTO.

Rejecting balancing is also right as a matter of economic theory. The proponent of balancing may argue that, whatever the WTO texts say, we need balancing to ensure global economic efficiency. Even a regulatory measure that is not protectionist and not unnecessarily trade-restrictive may have greater costs abroad than benefits at home (so the argument goes). Since the domestic regulator has no political incentive to consider the costs abroad, the dispute settlement system must balance the foreign costs against the domestic benefits to avoid inefficient results.

24 See the discussion of the Section 337 case in Section 3 above.

25 E.g., SPS 3.3, 4.1, 5.5, 5.6, TBT Preamble.

26 Notice that even subsidies to export industries, sometimes distinguished as 'export promotion', can be protectionism in the broad sense of regulation designed to improve the competitive position of some group of domestic economic actors vis-à-vis their foreign competitors.

27 Of course there are numerous more specific disciplines in the SPS and TBT Agreements, but even with regard to these, the 'least restrictive alternative' principle is what they seem primarily designed to implement, insofar as they are applied to non-discriminatory measures. And whatever the purpose of these more specific disciplines, an inquiry into whether a measure is based on a risk assessment, or whether it is based on an international standard, plainly does not require balancing. 
But this argument is fallacious. We do not actually need to balance the foreign costs against the domestic benefits, not even to secure global efficiency. The reason is that in the trade context (and given a general fact about countries' policymaking that I shall explain in the next paragraph), regulation by a Member that maximizes that Member's national social welfare is also globally efficient. I shall summarize this in the motto that 'domestically rational regulation is globally efficient'. This means that even if a tribunal reviewing some regulation is ultimately concerned with global efficiency, all it needs to investigate is whether the regulation is domestically rational. This does not trivialize the project of reviewing regulation. Countries often adopt regulation that is domestically irrational - for example, most protectionism, or well-motivated regulation that is unnecessarily trade-restrictive (which is domestically irrational because it harms domestic consumers unnecessarily, over and above harming foreign producers). There are serious questions about how tribunals should go about identifying domestic irrationality, and what sorts of domestic irrationality they can identify reliably enough so that they should be charged to try. But still, if the issue is domestic rationality, foreign costs are irrelevant. I cannot give an exhaustive demonstration here of the claim that domestically rational regulation is globally efficient. I have done so elsewhere. ${ }^{28}$ In a moment, I will offer an intuitive explanation. But first, let me comment on some assumptions.

First, the claim that domestically rational regulation is globally efficient is limited to the trade context. It is obviously not true in general. If a Member allows, or perhaps even requires, some local industry to dump noxious effluent into a river that flows into a neighboring country, that may very well be domestically rational but globally inefficient. But this is different from a trade law case, because the local environmental law (or lack of it), creates a physical cross-border externality what an economist would call a 'non-pecuniary' externality. In contrast, trade regulation creates only pecuniary externalities; the harm done to foreign interests is mediated through effects on market opportunities. This is a crucial difference. Second, the claim that domestically rational regulation is globally efficient depends on the assumption that countries do not choose trade-affecting regulation for the purpose of improving their terms-of-trade. Notice I am not denying that tradeaffecting policies affect the terms of trade; I am only denying that they are chosen on this ground. This is a controversial assumption in some quarters, but I have argued for it in detail elsewhere. ${ }^{29}$ There are further assumptions we must make before we can prove the claim in a mathematical model, but these two are the most salient. $^{30}$

28 Regan, 'What Are Trade Agreements For? - Two Conflicting Stories Told by Economists, With a Lesson for Lawyers', Journal of International Economic Law, 9(4), 951-988 (2006).

29 Ibid.

30 Other assumptions, aside from purely mathematical ones about convexity and the like, are (a) competitive domestic markets, (b) constant returns to scale, and (c) domestically rational behavior by all 
Even with these assumptions, why is it true that domestically rational regulation is globally efficient? Why do we not have to worry at some point about the foreign costs? Those costs are real even if they are only "pecuniary". Over the years I have experimented with a variety of metaphors and stories as intuitive explanations. Here are two. First, suppose that Home imports widgets from Foreign. Although it is individual consumers in Home who buy widgets, think of Home as a collective consumer of widgets. The collective interest is just the aggregate of all private interests in Home that are affected in any way by widget consumption in Home. If there is some market failure in the domestic market - a consumption externality, or consumer ignorance or irrationality, for example - then the demand curve for imported widgets that results from the unregulated market behavior of Home's individual widget consumers will not embody the true interests of the collective consumer Home. If Home now regulates rationally to correct the market failure, it will alter the incentives of individual consumers so that their aggregated behavior does reflect the true interests of the collective consumer. If we assume similarly that Foreign puts in place any regulation that may be necessary to make the supply curve for exports that results from the aggregated behavior of its producers reflect the true overall interests of the collective producer Foreign, then the intersection of Home's demand curve for imports and Foreign's supply curve for exports will identify an efficient result, in the standard way. The one danger posed by these 'collective' actors is that they will exploit their market power to manipulate their terms of trade (that is, they will behave as monopsonist or monopolist in the international market). But we have excluded that by hypothesis. So, if each country regulates rationally for its domestic interests, the market produces an efficient result. Domestically rational regulation is globally efficient.

The story we have just told emphasizes that separate self-interested regulations by Home and by Foreign combine to produce an efficient result, via the mechanism of the market. A different story (in which Home still imports widgets from Foreign) emphasizes that Home's widget consumers and Foreign's widget producers have a joint interest in being allowed to transact with each other on efficient terms. Hence Home's widget consumers can in a sense 'represent' Foreign's widget producers in Home's political process, and vice-versa. Let us assume specifically that consumption of widgets in Home creates a (domestic) consumption externality. (This is just one example to illustrate a general point.) To correct this externality, Home imposes a Pigovian tax. But they overestimate the externality, and they set the tax too high. ${ }^{31}$ Now, the too-high tax will create a deadweight loss, ${ }^{32}$ and this loss will be divided between consumers in Home and producers

other countries. Again, I have explained elsewhere why these are appropriate assumptions for the dispute settlement system to rely on, even though they are obviously idealizations. Ibid. at 982-983.

31 This is just a miscalculation by Home; by hypothesis, Home is not setting the tax above the efficient level as a means of purposeful terms-of-trade manipulation.

32 This assumes there is efficient regulation in Foreign, so that Home's too-high tax does not merely compensate for, say, an export subsidy in Foreign. 
in Foreign. ${ }^{33}$ That simple point is crucial: when the harm is market-mediated, any loss is shared. The fact that the loss is shared means that if Home now revises its policy so that it eliminates the deadweight loss on its own consumers, it will necessarily eliminate the deadweight loss on Foreign's producers as well. It's not that the loss of the consumers is the same as the loss of the producers; these losses are different; but they are linked. Because any deadweight loss is shared, reducing the deadweight loss felt by Home's consumers to zero means the deadweight loss felt by Foreign's producers must go to zero as well. In other words (and once again), regulation that is domestically rational will also be globally efficient.

In eschewing cost-benefit balancing and allowing Members to choose their own level of protection, the Appellate Body follows both treaty text and sound economic theory.

33 This assumes Home has market power as a buyer in the world market for widgets; if they do not, their policy cannot hurt Foreign in any event. 